\author{
Supporting Our Troops: \\ Library Services and Support for Veterans \\ Sarah LeMire \\ Texas A\&M University
}

Sarah LeMire

First Year Experience \& Outreach Librarian

Texas A\&M University

E-mail: slemire@ library.tamu.edu

Acknowledgments: Many thanks to David Hubbard, Sean Buckner, Stephanie Graves, and Lorelei Rutledge for providing feedback on a draft of this article. 


\title{
Support Our Troops: \\ Library Services and Support for Veterans
}

\begin{abstract}
Veterans are a unique population that can be found in libraries across the United States. Libraries of all types are developing new approaches to the veterans in their patron populations in the wake of the wars in Iraq and Afghanistan. This study identifies several common strategies that libraries, especially public and academic libraries, are employing to support their patrons who are veterans, as well as distinctions in strategy according to library type. It further explores whether libraries are relying upon library staff who are veterans when developing services and programming for patrons who are veterans.
\end{abstract}

Keywords: veterans, service members, student veterans, military, public libraries, academic libraries 


\section{Introduction}

In the wake of the wars in Iraq and Afghanistan, libraries have given new attention to veterans and service members as a unique patron population. Librarians have begun presenting about their efforts to support veteran and military-affiliated populations at conferences such as the American Library Association Annual Conference, Public Library Association Annual Conference, Association of College and Research Libraries Conference, and Texas Library Association Annual Conference (Blansett \& Blansett, 2012; Fawley \& Krysak, 2013; LeMire, 2015; LeMire, 2017; Roy, Mulvihill, Rickard, Taft, \& Olney, 2016; Tinoco \& Hoppenfeld, 2015). Other librarians have written up their efforts in journals such as Public Libraries, Reference Services Review, and Journal of Academic Librarianship (Atwood et al., 2016; Mills, Paladino, \& Klentzin, 2015; Taft \& Olney, 2014). However, there is little research that has examined the approaches employed across multiple types of libraries to respond to veteran and military-affiliated patrons.

This study is a first step toward gaining a better understanding of what strategies libraries are using to support their patrons who are veterans and explores the following research questions:

1) What are libraries doing to support veterans?

2) Are there differences in how different types of libraries are serving veterans?

3) Are libraries using veterans and service members within their own staff to connect with veterans?

\section{Literature Review}

Veterans, service members, and other military-affiliated groups are an important underserved community in many types of libraries. Although not one of the American Library 
Association's officially-designated underserved patron groups, veterans and service members have a number of specific challenges and unique characteristics that require libraries to treat them as a community that can experience barriers to library access. One important difference that challenges veterans' library access is that they are much more likely than civilians to have a disability. Although the American Community Survey estimates that the overall U.S. rate of disability is $12.6 \%$, over $17 \%$ of all veterans and over $30 \%$ of Post-9/11 veterans have a serviceconnected disability (Kraus, 2015; U.S. Department of Veterans Affairs, 2014; U.S. Department of Veterans Affairs. National Center for Veterans Analysis and Statistics, 2015; U.S. Department of Veterans Affairs. Veterans Benefits Administration, 2015). Veterans and service members can also face significant challenges during the reintegration period, as they transition from military service to civilian life. Demers (2011) found that veterans of the wars in Iraq and Afghanistan reported "high levels of distress" as well as "feeling alienated from family and friends, and experiencing a crisis of identity" when they transitioned from military to civilian life (p. 160). Another important way in which veterans and service members differ from civilians is that they tend to be adherents to military culture, which diverges significantly from civilian culture. For example, military culture praises adherence to core military values such as discipline, selfsacrifice, and "obedience to legitimate authority," values that can sometimes be at odds with civilian society, which prioritizes the individual (Collins, 1998, p. 217). This can leave veterans and service members feeling isolated and out of place in civilian environments. Additionally, on college and university campuses, student veterans and service members are an at-risk population. In a recent American Council on Education study, Molina \& Morse (2015) found that over 90\% of reservist students and $100 \%$ of active duty service member and veteran students exhibit at least one risk factor for not completing college. These non-completion risk factors include 
characteristics such as delayed enrollment in college, part-time enrollment, and working fulltime during college. Further, they found that the majority of these military-connected undergraduates exhibit multiple non-completion factors, with some veteran and service member students exhibiting as many as six or more non-completion factors (Molina \& Morse, 2015). These types of characteristics make veterans and service members a patron group with its own unique barriers to accessing library facilities and library resources.

Recognizing the uniqueness of this population, libraries have begun working to improve their support for veteran and military-affiliated populations in a number of ways, as is evidenced by the recent proliferation of case studies sharing veteran outreach success stories. Public libraries have initiated efforts such as participation in the Library of Congress' Veterans History Project and book club meetings at local veterans service organizations (Baranowski, 2009; Watkins, 2013). Academic libraries also support veterans and service members. Some libraries with a significant population of active duty service member students have developed strategies for supporting these students, such as embedding in Blackboard or partnering with a local military base to develop joint programming (Landers \& Youngman, 2009; Whited \& Frederick, 2015). Other academic library efforts include developing or participating in orientation sessions for veterans, embedding in programs such as the Entrepreneurship Bootcamp for Veterans, developing veteran-oriented displays and programs, and building veteran-oriented collections (Atwood et al., 2016; Hudson, 2016; Hoppenfeld, Wyckoff, Henson, Mayotte, \& Kirkwood, 2013; LeMire, 2015; Sopiarz, 2016).

Although library literature discusses a variety of attempts to connect with veterans, there is little discussion of veteran culture and how it impacts successful library outreach efforts. Service in the U.S. military is a bonding experience, as service members have to develop a 
cohesive dynamic. The collectivistic nature of military training bonds service members together (McGurk, Cotting, Britt, \& Adler, 2005), a dynamic further strengthened by the stresses of combat (Henderson, 1985). Once service members depart the military, veterans often miss the camaraderie and support of their comrades in arms (Saslow, 2014). Veterans who enroll in colleges and universities after their service express the same desire for interaction with others who have served in the military (Arminio, Grabosky, \& Lang, 2015; Elliott, Gonzalez, \& Larsen, 2011; Summerlot, Green, \& Parker, 2009). Student veterans feel disconnected from traditional college students, who often have little ability to relate to the challenges faced and sacrifices made by veterans during their service. In response to veterans' desire to connect with other veterans on campus, many universities have developed veterans' lounges or centers where student veterans can interact with one another (McBain, Kim, Cook, \& Snead, 2012).

Some libraries have become involved in these efforts by developing veteran-themed spaces in the library or creating dedicated spaces for student veterans and service members (LeMire \& Mulvihill, 2017; Samson, 2016). Many public libraries have made strides toward making the library more explicitly welcoming and inclusive for veterans. Public librarians near Fort Bragg, North Carolina studied military family members and found that programs such as a military book discussion group, military-themed exhibits, and military-related author visits might be well-received (Taft \& Olney, 2014). In one of the few studies that examined multiple institutions, Roy, Barker, Hidalgo, and Rickard (2016) reviewed the literature and library websites to find that public libraries in 42 states offered programming and services for veterans, ranging from participation in the Veterans History Project to permanent displays to recognition ceremonies. 
In addition to efforts to make the library space more welcoming for veterans and service members, librarians have been working to reduce veterans' and service members' barriers to information access. Academic librarians Mills, Paladino, and Klentzin (2015) found that student veterans are inclined to seek help from an expert and that information literacy instruction may be well-received by this group. And Lynch (2008) and Murphy (2009) studied deployed military personnel to identify barriers to information access while deployed, finding that service members can have significant access limitations and may not be aware of available library services.

Outreach and programming aimed at patrons who are veterans are important strategies that libraries can use to increase their support for veterans and service members in their communities and on their campuses. Librarians have long used outreach and programming to support underserved populations. Some libraries have used outreach strategies such as exhibits, panel discussions, and invited guest speakers to make the library more explicitly welcoming to underserved populations such as LGBTQ college students, student veterans, and patrons with autism spectrum disorders (Remy \& Seaman, 2014; Rutledge \& LeMire, 2016). Other libraries have employed outreach strategies that overcome access barriers by bringing library resources directly to underserved patrons, such as providing storytime at homeless shelters or for a class of physically challenged students at a local school (Mars, 2012; Vogel, 2008). As libraries continue to recognize the importance of providing outreach, programming, and collections for their veteran and military-affiliated populations, research into the strategies employed by libraries already invested in veteran and service member patrons will be critical to informing their efforts.

\section{Methodology}

Because of the insular nature of the veteran community, it can be challenging for outsiders to make strong connections with veterans and service members. The implications for 
researchers with insider status in marginalized groups have been well-established by the literature (Merriam et al., 2001; Yakushko, Badiee, Mallory, \& Wang, 2011). Advantages of insider status may include increased access to study communities, but the same proximity to research subjects that can help gain trust can also prove to be a disadvantage, as clarity and perspective can also be a challenge (Corbin Dwyer \& Buckle, 2009).

Although insider/outsider status for researchers has been explored in depth, the relationship between insider status and the efficacy of academic outreach activities is a new area to explore. Within libraries, outreach is an increasingly important topic, as librarians endeavor to engage students and ensure that they are familiar with library resources (e.g., Hanna, Cooper, \& Crumrin, 2011; Smallwood, 2010; Westbrook \& Waldman, 1993). But the relationship between insider/outsider status and library outreach is unclear. For example, Lymn (2013) explores the idea of "librarian-as-insider-ethnographer" in relationship to acquiring library materials, but does not extend this concept to outreach and reaching new user groups. And there is no research regarding librarians who are veterans using their insider status to reach patrons who are military service members or military veterans. This study, conducted by a librarian with insider status as a military veteran and military spouse herself, explores as one of its research questions whether librarians are using the veteran and military community insiders within their own organizations in order to improve their outreach efforts to patrons who are veterans.

In order to determine how different types of libraries support the needs of their patrons who are veterans, a survey was distributed via several popular library listservs as well as via common social media outlets. The survey was constructed in Qualtrics and launched in January 2016 via library listservs aimed at public librarians (publib), academic librarians (uls-1, collib-1, acr-iglmo, SLA Academic Division), special librarians (faflrt, prison-1), and lists that are aimed 
at a variety of library types (rusa-1, ili-1, nmrt-1, libref-1). The survey was also disseminated via social media, including Facebook and Twitter. The survey was sent on a staggered schedule beginning January 12, 2016, with a final reminder sent on January 25, 2016. The survey was closed to additional responses on January 31, 2016.

The survey was divided into four sections. The first section, Demographics, asked respondents to provide basic demographic information about themselves, including type of library. The second section, Your Library's Services for Veterans, asked respondents to provide information about their library's services for veterans, including whether their library had a liaison to veterans and whether that liaison had a military background. The third section, Your Military/Veteran Affiliation, asked respondents about their own military background. Finally, the Follow Up section asked respondents for information about how they would prefer to learn more about library services for veterans. This study summarizes some of the survey data and highlights the important findings.

\section{The Data Set}

There were 182 responses to the survey, of which 155 were valid, complete responses. Table 1 shows the distribution of responses by library type. There were insufficient responses for K-12, Special, and Other library types to draw any conclusions, so this study will not break out patterns for those library types.

\begin{tabular}{|l|r|}
\hline Type of Library & Number of Responses \\
\hline Academic/Research & 102 \\
\hline K-12 & 2 \\
\hline Public & 41 \\
\hline Special & 2 \\
\hline Other & 8 \\
\hline Total & 155 \\
\hline \multicolumn{2}{|l}{} \\
\hline
\end{tabular}




\section{Coding}

Of the 155 valid responses, $86(55 \%)$ reported that their libraries offered programs or services for veterans, while 27 (17\%) reported that they were not sure if their libraries offered programs or services for veterans and $42(27 \%)$ reported that their library did not offer any programs or services for veterans. The survey then used branching logic to ask the 113 respondents whose libraries did or might have services for veterans to share the types of programs and/or services that were available at their libraries, and 89 respondents provided a response to this question. Using a grounded theory approach, these short-answer responses were coded by the author into the eight broad categories shown in Table 2.

\begin{tabular}{|l|l|}
\hline Category & Types of Activities Included \\
\hline Administrative & Policies enacted to support veterans, including veterans who employees \\
\hline Website & Website dedicated to information for veterans, including LibGuides \\
\hline Services & $\begin{array}{l}\text { Mediated and unmediated interventions such as information literacy } \\
\text { instruction, workshops, office hours, reference support, tutorials, and } \\
\text { liaisons }\end{array}$ \\
\hline Collaborations and & $\begin{array}{l}\text { Relationships with and referrals to military and veteran-related } \\
\text { organizations, including campus veterans centers, military installations, } \\
\text { and veterans service organizations }\end{array}$ \\
\hline Outreach & $\begin{array}{l}\text { Orientations, tours, resource fairs, and other outreach activities aimed } \\
\text { at veterans }\end{array}$ \\
\hline Spaces & $\begin{array}{l}\text { Library spaces dedicated to veterans, either on a permanent or an } \\
\text { intermittent basis }\end{array}$ \\
\hline Collections & $\begin{array}{l}\text { Collection development efforts aimed at veterans, including separate } \\
\text { military or veteran-themed collections }\end{array}$ \\
\hline Programs & $\begin{array}{l}\text { Events and activities aimed at veterans, including book clubs, study } \\
\text { groups, oral history projects, support groups, and exhibits }\end{array}$ \\
\hline
\end{tabular}

Table 2: Categories of Library Programs and Services for Veterans

\section{Findings}

The 89 responses, which include responses from all types of libraries, are a convenience sample that does not lend itself to generalizable conclusions. However, respondents' descriptions 
of their libraries' programs and services demonstrate that libraries are striving to support veterans in a number of different capacities. A significant portion of these library efforts take the form of making personal contact with the veteran community, as programs, services, and outreach account for half of the responses, which would include activities such as liaisons, reference services, book clubs, tours, and oral history projects.

\section{Library Efforts to Serve Patrons who are Veterans}

Figure 1 presents the most common strategies that libraries are employing to serve their patrons who are veterans. The most common effort detailed in survey responses was veteranoriented programs or events (e.g., library-sponsored panels, luncheons, Veterans Day events), with 39 respondents $(21 \%)$ reporting that their library has developed some type of program for veterans. This was followed closely by services, which included efforts such as reference and instruction. Other common responses included spaces designated for veterans, either on a permanent or intermittent basis, outreach efforts (e.g., presentations, flyers, resource fairs) and partnering with a veteran organization on campus or in the community. Another common effort, particularly in academic libraries, was to develop a LibGuide. Most respondents who mentioned a LibGuide also mentioned other programs, services, or collections, which may suggest that LibGuides are perceived to be less useful if not accompanied by additional efforts. 


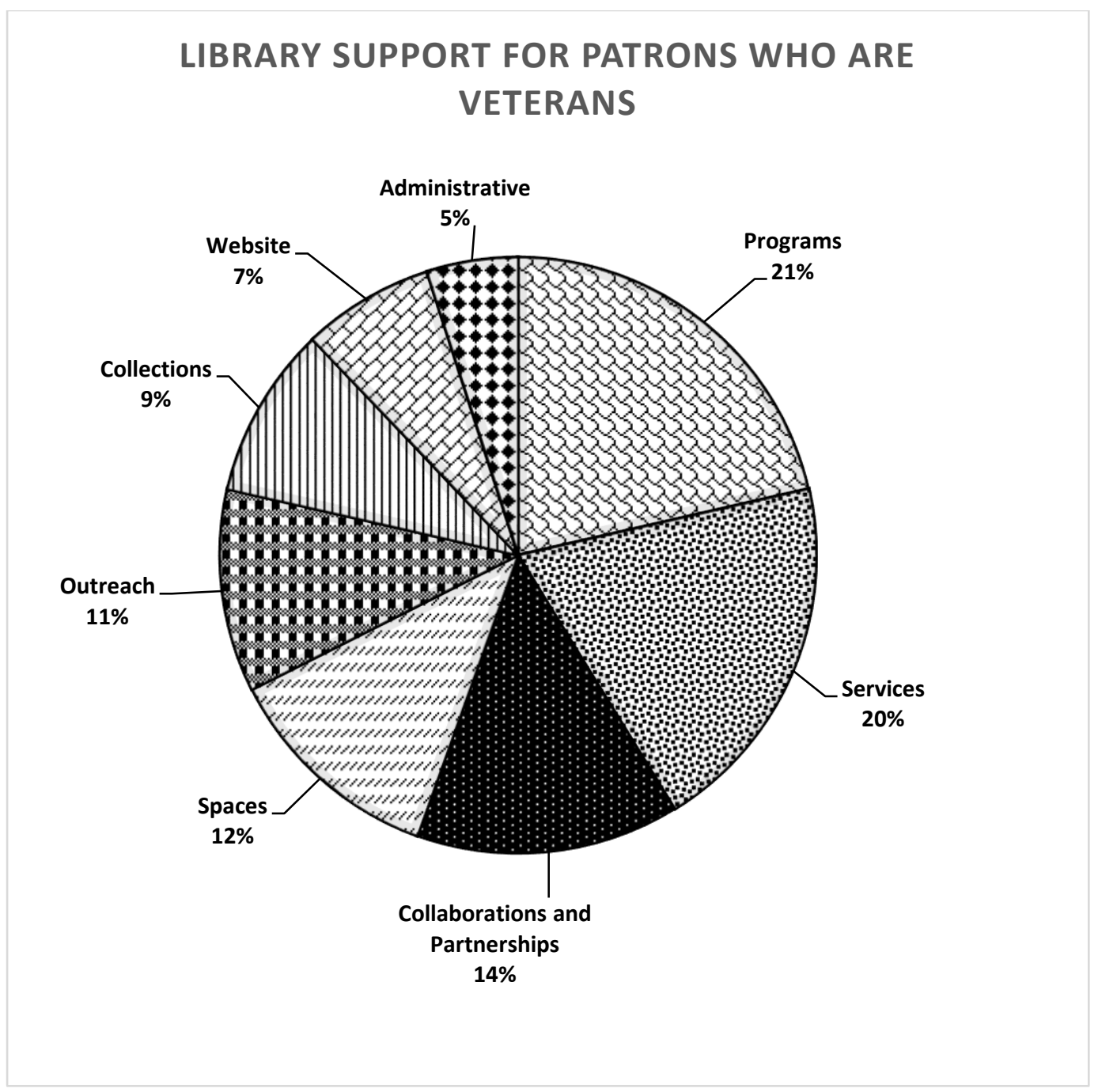

Additionally, there are some distinct differences between the efforts reported in public libraries versus academic libraries. Public and academic libraries diverge in the strategies they use to engage patrons who are veterans. Public library respondents were more likely to mention that their library offers a space designated for veterans. Nine respondents (17\%) from public libraries mentioned that they provide specific spaces for veterans, in contrast to 11 respondents (9\%) from academic libraries. This may be related to the popularity of the Veterans Connect @ the Library program, an IMLS-sponsored program developed by the California State Library to provide services for veterans in public libraries. One of the Veterans Connect @ the Library program requirements is that participating libraries provide Veteran Resource Centers in their 
libraries (Veterans Connect, 2016). Furthermore, public librarians are more likely to develop programs for their patrons who are veterans. Among public library respondents, 13 (25\%) reported developing programs for veterans, in contrast with 23 academic library respondents (19\%). Academic librarians, however, were more likely to mention services that support a variety of patrons on campus, such as reference assistance, information literacy instruction sessions, and personal librarian programs, in which students are assigned to a specific librarian. This may suggest that public libraries are more readily able to incorporate strategies for working with veterans as a unique patron group, while academic libraries may still be struggling to identify how student veterans differ from their civilian counterparts and to meet those unique needs accordingly.

\begin{tabular}{|l|r|r|}
\hline Category & Academic Libraries & Public Libraries \\
\hline Administrative & 6 & 3 \\
\hline Collaborations and Partnerships & 23 & 11 \\
\hline Collections & 10 & 6 \\
\hline Outreach & 15 & 4 \\
\hline Programs & 23 & 13 \\
\hline Services & 22 & 4 \\
\hline Spaces & 11 & 9 \\
\hline Website & 10 & 2 \\
\hline
\end{tabular}

Table 3: Frequency of Category Response by Library Type

\section{Veterans as Liaisons}

Some veterans, service members, and family members of veterans and service members can feel a strong call to give back to the veteran and military community. Furthermore, veteran culture prioritizes communication and connections with others who have served. Therefore, this study explored whether libraries that were making efforts to connect with patrons who are veterans were employing members of their own staff who had personal ties to this community. Survey results showed that many of the libraries that have services for veterans have officially 
designated a liaison or committee responsible for coordinating work with the veteran and military community. Of the 103 public and academic libraries reporting that their libraries were or might be involved in veterans' issues, 19 respondents (68\%) from public libraries and 40 respondents (53\%) from academic libraries reported that their library had a designated liaison.

And, indeed, many of these liaisons have a relationship to the veteran and military community. Although only 15 respondents ( $25 \%$ of those with a liaison) reported that the liaison was a veteran or service member themselves, 28 respondents ( $47 \%$ of those with a liaison) reported that their liaison had some relationship to the veteran and military community. Public libraries are more likely to have a liaison with military ties, with 10 respondents $(52 \%$ of those with a liaison) from public libraries indicating that their liaison is a veteran, service member, or family member of a service member (Figure 2).

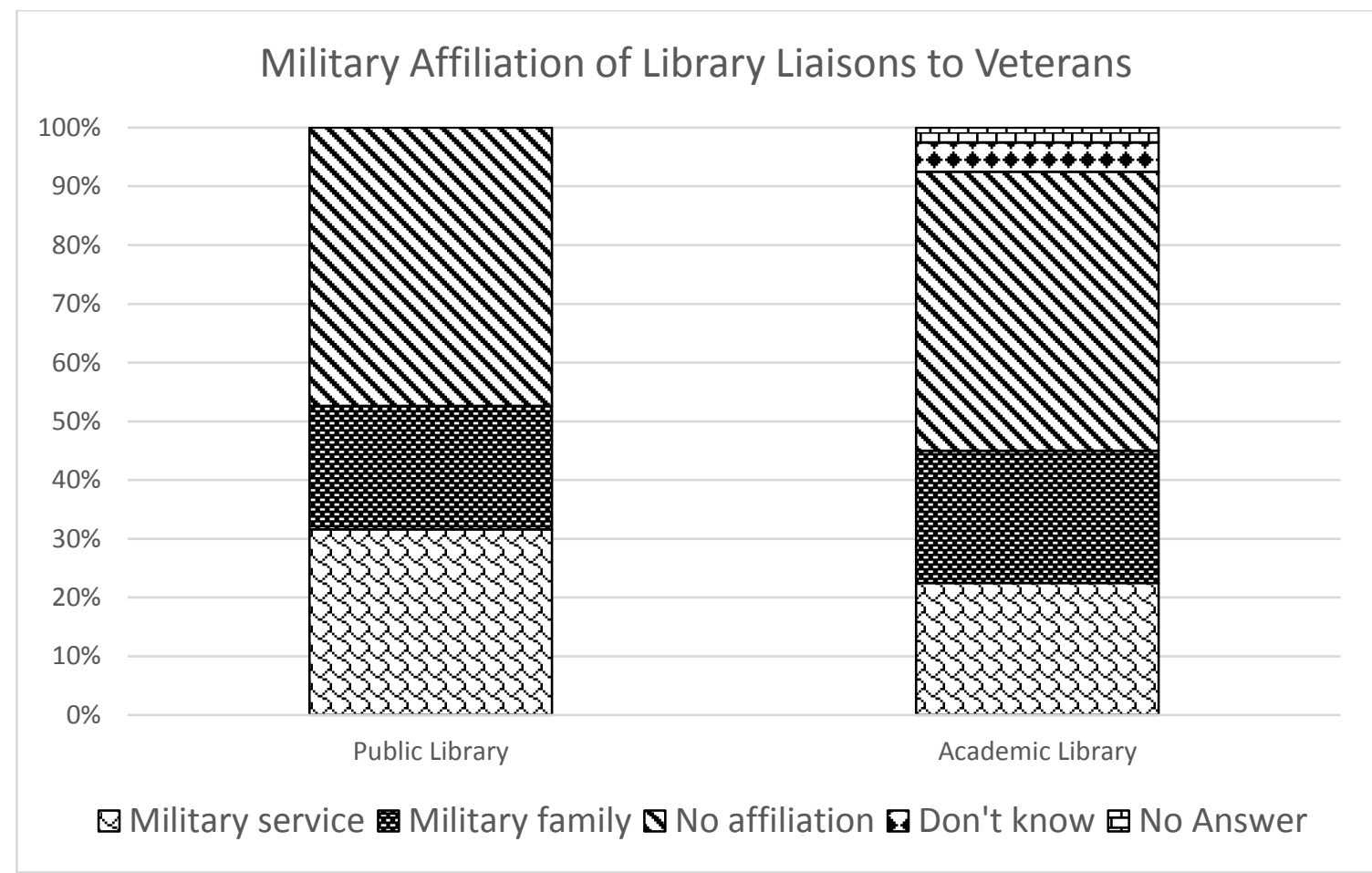




\section{Discussion}

This research reveals that, while libraries are making strides toward serving this important patron population, considerable work remains to be done. Of the survey's respondents, $42(27 \%)$ reported that their library offered no services or programming for veterans, while another 27 respondents $(17 \%)$ did not know if their library offered services or programming. Although this means that over half (86 respondents, or 55\%) reported that their library that provided specific services for veterans, the actual percentage is expected to be much lower as those who were already working with veterans would be more likely to respond to the survey than those who were not.

For the libraries that are providing specific support for patrons who are veterans, the type of support depended largely on the type of library. A slightly higher percentage (59\% vs. 56\%) of public library respondents reported that their libraries were engaged in some type of efforts aimed at veterans. Although this is neither a representative sample nor a statistically significant difference, this data may correspond with anecdotal indications suggesting that public libraries have been faster than academic libraries to embrace patrons who are veterans in the wake of the wars in Iraq and Afghanistan. Academic libraries have been slow to join efforts on college and university campuses to better serve student veterans (LeMire, 2015), while public libraries, particularly those in California, have actively engaged the veteran and military community through programs such as Veterans Connect @ the Library (Veterans Connect, 2016). Furthermore, these numbers could also suggest that academic libraries are quickly catching up to their public library peers in working with veteran and military-affiliated patrons.

Although the majority of the respondents reporting library involvement in working with veterans (57 respondents, or $66 \%$ of those reporting involvement) were from academic libraries, 
these respondents frequently mentioned services to veterans that also fall within their normal suite of services, including reference support, information literacy instruction, personal librarian programs, and developing LibGuides. In contrast, public librarians were more likely to mention specific programming for veterans, such as exhibits or displays, book clubs, or programs. This may suggest that academic librarians can benefit from working with their public librarian peers to better identify strategies for developing programs and services that are oriented directly toward veterans.

Both public and academic libraries have recognized the importance of developing collaborations and partnerships in order to connect with veterans. Academic library respondents frequently mentioned partnering with a campus veterans center or a student veterans association, both of which are campus organizations that are already striving to meet the needs of the student veteran and service member populations, as well as with initiatives such as the Entrepreneurship Bootcamp for Veterans (EBV). Public libraries mentioned partnering with local stakeholders such as a County Veterans Service Officer as well as with state-wide organizations such as California’s Veterans Connect @ the Library program. These partnership efforts can be an effective way for librarians to learn more about the needs and strengths of the veteran and service member populations and also to be sure that the library's efforts are not redundant or conflicting with the efforts of other local organizations.

Several respondents, both in public and academic libraries, have recognized that the library can play a role not only in helping patrons who are veterans overcome their challenges, but also in highlighting their strengths. Much of the library literature about veterans and service members focuses on fulfilling the needs of this unique patron group, but this narrative is one that the veteran and military community resists. Veterans believe that their service provides them 
with strengths that they can bring back to the civilian community, and they are likely to resist library efforts that position them as being in need (LeMire, 2015). Respondents described programs such as panel discussions, student veteran-organized exhibits, and Veterans History Project participation that give veterans the opportunity to share their experiences with the larger patron community and receive recognition for their contributions.

Finally, approximately $7.3 \%$ of the U.S. population has served in the military (Chalabi, 2015). However, libraries with liaisons to the veteran community reported that a much higher percentage of these liaisons were veterans or service members - $25 \%$. And $47 \%$ of the libraries with a liaison to patrons who are veterans report that their liaison has some military affiliation, either as a veteran or as a close family member. This suggests that libraries may be more likely to recognize veterans as a unique patron population if they have internal personnel with a military background who are personally interested in providing support for the veteran and military community. Due to the insular dynamic of the veteran and military community, the strategy of using veterans and service members on staff as liaisons can be a smart move to build trust with veteran and military-affiliated patrons. But, as with other underserved communities, it is problematic to rely too heavily on members of those communities to provide support. Even libraries without staff members who have a personal relationship to the military should be considering whether their patron community includes veterans and service members who could benefit from targeted programs and services.

\section{Future Research}

The body of literature relating to veterans and service members in libraries remains underdeveloped. Further research is necessary in order to better understand which libraries are choosing to serve veterans and service members as a unique patron group, including the role that 
the military status of librarians and library staff plays in that choice. Additional research is also necessary to uncover which programs veteran and military-affiliated patrons would like to see in libraries, as well as to investigate the efficacy and impact of specific library outreach, programs, and services for veterans and service members.

\section{Conclusion}

Although this study demonstrates that many types of libraries, especially public and academic libraries, have begun efforts to support their patrons who are veterans, the limited number of responses may indicate that these efforts are not yet widespread. Libraries that are serving veterans are focusing their support in a few key areas, with services, programs, and collaborations and partnerships the most common strategies employed by libraries. While these are the most common services overall, this study suggests that public libraries and academic libraries approach their patrons who are veterans differently. Public libraries are more likely to report developing programming specifically oriented toward their patrons who are veterans, while academic libraries are more likely to report that they support student veterans through general library services such as reference or instruction. Finally, this study suggests that libraries do rely heavily on librarians and staff members with insider status in the veteran and military community when supporting their patrons who are veterans. The percentage of reported liaisons who are veterans or service members far exceeds the percentage of veterans and service members in the general community.

Libraries that are just beginning to work with patrons who are veterans, as well as libraries with more established programs, can garner ideas from the activities reported by this study's respondents. Libraries across the country are taking a variety of approaches to supporting their patrons who are veterans, and the best approach can vary widely based upon the veterans' 
needs, availability of resources, and institutional context. However, one of the first steps that libraries can take is to establish a liaison to the veteran and military community. As an insular community, it can take time and sustained effort for librarians to build trust and develop buy-in, so it can be beneficial to designate a specific liaison who is responsible for developing and maintaining a relationship with patrons who are veterans, local veterans service organizations, and other stakeholders on campus or in the area. Liaisons can also play a central role in developing new library programs and services and can advocate to library leadership for veteranfriendly policies and spaces. Although it can be helpful for designated liaisons to have insider status in the veteran and military community, in the author's experience, the most important element in a successful liaison is an appreciation for military service and a sincere desire to support military veterans and service members.

Finally, as libraries continue to respond to the call to better support their patrons who have served in the military, librarians must continue to explore how they can build upon the efforts of their colleagues in the profession and in the veterans service community and how they can make data-driven decisions about programming, services, and collections to support veteran and military-affiliated patrons. Veterans and service members are a unique population with their own dynamics, their own needs, and their own strengths to bring to the community. Libraries, as linchpins for their communities, can play an important role in helping veterans and service members transition to civilian life, get connected to the resources they need, and build upon their assets to support one another and the larger community.

\section{References}

Arminio, J., Grabosky, T.K., \& Lang, J. (2015). Cultural context. In Student veterans and service members in higher education (pp. 21-43). New York: Routledge. 
Atwood, T., Farmer, M., McDonald, K., Miller, B., Theodore-Shusta, E., \& Wood, E.J. (2016). On the front lines: Serving Ohio's best. Journal of Academic Librarianship, 42(2), 172180. doi:10.1016/j.acalib.2015.12.011

Baranowski, R. (2009). Now hear this!: Veterans' stories live on in oral narratives as local library assists in congressional history project. Public Libraries, 48(3), 32-37.

Blansett, J. \& Blansett, C. (2012). Invisible wounds, invisible warriors: How can libraries meet the needs of these students? Poster session presented at the annual meeting of the American Library Association, Anaheim, CA.

Chalabi, M. (2015, March 19). What percentage of Americans have served in the military? [Blog post]. Retrieved from http://fivethirtyeight.com/datalab/what-percentage-of-americanshave-served-in-the-military/

Collins, J.J. (1998). The complex context of American military culture: A practitioner's view. Washington Quarterly, 21(4), 213-228. doi:10.1080/01636609809550359

Corbin Dwyer, S., \& Buckle, J.L. (2009). The space between: On being an insider-outsider in qualitative research. International Journal of Qualitative Methods, 8(1), 54-63.

Demers, A. (2011). When veterans return: The role of community in reintegration. Journal of Loss and Trauma, 16(2), 160-179. doi:10.1080/15325024.2010.519281

Elliott, M., Gonzalez, C., \& Larsen, B. (2011). U.S. military veterans transition to college: Combat, PTSD, and alienation on campus. Journal of Student Affairs Research and Practice, 48(3), 279-296. doi:10.2202/1949-6605.6293

Fawley, N. \& Krysak, N. (2013). Serving those who serve: Outreach and instruction for student cadets and veterans. In Mueller, D. (Ed.) Imagine, innovate, inspire: The proceedings of 
the ACRL 2013 conference (pp. 525-531). Chicago, IL: Association of College and Research Libraries.

Hanna, K.A., Cooper, M.M., \& Crumrin, R.A. (2011). Diversity programming and outreach for academic libraries. Oxford, UK: Chandos Publishing.

Henderson, W.D. (1985). Cohesion: The human element in combat. Washington, D.C.: National Defense University Press.

Hoppenfeld, J., Wyckoff, T., Henson, J. A. J., Mayotte, J. N., \& Kirkwood Jr, H. P. (2013). Librarians and the Entrepreneurship Bootcamp for Veterans: Helping disabled veterans with business research. Journal of Business \& Finance Librarianship, 18(4), 293-308. doi:10.1080/08963568.2013.825227

Hudson, A. (2016). Academic librarian outreach to veterans: Giving back to those who served. Mississippi Libraries, 79(2), 47-49.

Kraus, L. (2015). 2015 disability statistics annual report. Durham, NH: University of New Hampshire. Retrieved from http://www.disabilitycompendium.org/docs/defaultsource/2015-compendium/annualreport_2015_final.pdf

Landers, M.J. \& Youngman, D.C. (2009). Academic libraries on the front lines: Advancing the library through a partnership with the U.S. Army. College \& Undergraduate Libraries, 16(2-3), 211-220. doi:10.1080/10691310903001481

LeMire, S. (2015). Beyond service: New outreach strategies to reach student veterans. In Creating Sustainable Community: The Proceedings of the ACRL 2015 Conference (pp. 66-71). Chicago, IL: Association of College and Research Libraries.

LeMire, S. (2017). Veterans and military communities: Serving those who served. Presentation at the annual meeting of the Texas Library Association, San Antonio, TX. 
LeMire, S. \& Mulvihill, K. (2017). Serving those who served: Librarian's guide to working with veteran and military communities. Santa Barbara, CA: Libraries Unlimited.

Lymn, J. (2013). The librarian-as-insider-ethnographer. Journal of Library Innovation, 4(1), 1-9.

Lynch, J.A. (2008). Providing library services to deployed Army medical providers in Iraq and Afghanistan. Journal of Hospital Librarianship, 8(2), 218-229.

doi:10.1080/15323260801928555

Mars, A. (2012). Library service to the homeless. Public Libraries, 51(2), 32-35.

McBain, L., Kim, Y.K., Cook, B., \& Snead, K. (2012). From soldier to student II: Assessing campus programs for veterans and service members. Washington, D.C.: American Council on Education. Retrieved from http://www.acenet.edu/news-room/Pages/FromSoldier-to-Student-II.aspx

McGurk, D., Cotting, D.I., Britt, T.W., \& Adler, A.B. (2005). Joining the ranks: The role of indoctrination in transforming civilians to service members. In A.B. Adler, C.A. Castro, \& T.W. Britt (Eds.), Military life: The psychology of serving in peace and combat. Volume 2: Operational stress (pp. 13-31). Westport, Conn.: Praeger Security International.

Merriam, S.B., Johnson-Bailey, J., Lee, M-Y., Kee, Y., Ntseane, G., \& Muhamad, M. (2001). Power and positionality: Negotiating insider/outsider status within and across cultures. International Journal of Lifelong Education, 20(5), 405-416. doi:10.1080/02601370120490

Mills, C. P., Paladino, E. B., \& Klentzin, J. C. (2015). Student veterans and the academic library. Reference Services Review, 43(2), 262-279. doi:10.1108/RSR-10-2014-0049 
Molina, D. \& Morse, A. (2015). Military-connected undergraduates: Exploring differences between National Guard, Reserve, active duty, and veterans and in higher education. Washington, D.C.: American Council on Education.

Murphy, E.W. (2009). Delivery to the sharp end of the spear: Responding to the need for library support to the deployed and downrange military community. Journal of Library Administration, 49(1), 51-57. doi:10.1080/01930820802310676

Remy, C., \& Seaman, P. (2014). Evolving from disability to diversity. Reference \& User Services Quarterly, 54(1), 24-28. doi:10.5860/rusq.54n1.24

Roy, L., Barker, M., Hidalgo, L.L., \& Rickard, F.A. (2016). Public library services for veterans: Selected brief case studies. Public Library Quarterly, 35(3), 222-242. doi:10.1080/01616846.2016.1210452

Roy, L., Mulvihill, K., Rickard, F., Taft, J., \& Olney, C. (2016). Services to those who serve: Library programs for veterans and active duty military families. Presentation at the annual meeting of the Public Library Association, Denver, CO.

Rutledge, L. \& LeMire, S. (2016). Beyond disciplines: Providing outreach to underserved groups by demographic. Public Services Quarterly, 12(2), 113-124. doi:10.1080/15228959.2016.1157565

Samson, S. (2016). Student veterans in the academic library. College \& Undergraduate Libraries, 24(1), 80-89. doi:10.1080/10691316.2015.1125318

Saslow, E. (2014, April 19). 'Ugh. I miss it.': Transitioning from military to civilian life, and from camaraderie to isolation. Washington Post. Retrieved from http://www.washingtonpost.com/sf/national/2014/04/19/ugh-i-miss-it/ 
Smallwood, C. (Ed.). (2010). Librarians as community partners: An outreach handbook.

Chicago: American Library Association.

Sopiarz, J. (2016). Library outreach to veterans: Opportunities, challenges, examples. Active Librarian, 1(2), 1-14.

Summerlot, J., Green, S-M., Parker, D. (2009). Student veterans organizations. New Directions for Student Services, 2009(126), 71-79. doi:10.1002/ss.318

Taft, J. \& Olney, C. (2014). Library services for the "new normal" of military families. Public Libraries, 53(6), 28-33.

Tinoco, E. \& Hoppenfeld, J. (2015). Boots on the ground: Making academic libraries work for veterans. Presentation at the annual meeting of the American Library Association, San Francisco, CA.

U.S. Department of Veterans Affairs (2014). VETPOP 2014: Living veterans by period of service, gender, 2013-2043. Retrieved from http://www.va.gov/vetdata/docs/Demographics/New_Vetpop_Model/2L_VetPop2014.xls $\mathrm{X}$

U.S. Department of Veterans Affairs. National Center for Veterans Analysis and Statistics (2015). Profile of Post-9/11 veterans: 2013. Retrieved from http://www.va.gov/vetdata/docs/SpecialReports/Post_911_Veterans_Profile_2013.pdf

U.S. Department of Veterans Affairs. Veterans Benefits Administration (2015). FY 2014 annual benefits report - compensation section. Retrieved from http://www.benefits.va.gov/REPORTS/abr/ABR-Compensation-FY14-10202015.pdf Veterans Connect @ the Library (2016). Retrieved from http://www.calibrariesforveterans.org/ 
Vogel, V. (2008). Library outreach to teens with physical challenges. Young Adult Library Services, 7(1), 39-42.

Watkins, C. (2013). From the front lines to the front desk. ILA Reporter, 31(3), 12-15.

Westbrook, L., \& Waldman, R. (1993). Outreach in academic libraries: Principle into practice. Research Strategies, 11(2), 60-65.

Whited, C. \& Frederick, G. (2015). Embedded with the military: It's all about the relationships. Journal of Library \& Information Services in Distance Learning, 9(1-2), 179-187. doi:10.1080/1533290X.2014.946358

Yakushko, O., Badiee, M., Mallory, A., \& Wang, S. (2011). Insider outsider: Reflections on working with one's own communities. Women \& Therapy, 34(3), 279-292. doi:10.1080/02703149.2011.580685 